Ain Mäesalu

\title{
THE ARTISTIC PAPSAARE MACEHEAD - WEAPON OR SYMBOL OF POWER?
}

\section{INTRODUCTION}

On 25 October 2016, a cast-bronze macehead was found in a meadow in the village of Papsaare, in Audru Rural Municipality, Pärnu County. ${ }^{1}$ This was not simply a weapon, but truly a work of art, which was also a unique object, because maceheads with images of two human faces have not been found before in Estonia or the rest of Europe.

Viewed more broadly, the Papsaare find can be placed among the bronze and iron maceheads that were found in the countries of East, Southeast and Central Europe, as well as Scandinavia, and Great Britain, primarily from the $11^{\text {th }}$ to the $14^{\text {th }}$ century. The maceheads that have been found in many countries have been thoroughly analysed and various types have been identified. Therefore, a good overview

DOI: https://doi.org/10.12697/BJAH.2017.13.05

Translated by Juta Ristsoo.

1 The macehead was found by amateur historian Arne Ankru using a metal detector. 
exists of the finds from Russia, ${ }^{2}$ Hungary, ${ }^{3}$ Bulgaria, ${ }^{4}$ Belarus, Ukraine, ${ }^{6}$ Poland,${ }^{7}$ Latvia, ${ }^{8}$ Sweden ${ }^{9}$ and Great Britain. ${ }^{10}$

Only three bronze and one iron macehead, which originate from the $12^{\text {th }}$ to $13^{\text {th }}$ century, have been found in Estonia to date. ${ }^{11}$

The great majority of the maceheads found in Europe until now have sharp corners, protruding spikes, knops and ribs; and simpler geometric ornamentation can be found on a certain portion of them. Besides the Papsaare macehead with images of two different human faces, only two similar maces have been found, one in Sweden and the other in Norway, although these only feature a single face. However, only a few sentences have been published about them. ${ }^{12}$ In addition, one macehead with two full-length human figures have been found in the Åland Islands of Finland. ${ }^{13}$

2 Анатолий Кирпичников, “Древнерусское оружие, 2. Копья, сулицы, боевые топоры, булавы, кистени IX-XIII вв”, Археология СССР. Свод археологических источников, вып. Е I - 36 (Москва: Наука, 1966), 47-57.

3 László Kovács, “A Magyar Nemzeti Múzeum fegyvertárának XI-XIV. századi csillag alakú buzogányai", Folia Archaeologica, 22 (1971), 165-181.

4 Stoyan Popov, The Maces from the Present Bulgarian Lands $\left(10^{\text {th }}-17^{\text {th }} \mathrm{c}\right.$. AD) (Sofia: Ivrai, 2015).

5 Николай Плавинский, “Булавы конца IX-XIII вв. на территории Беларуси”, Археология и история Пскова и Псковской земли. Семинар имени академика В. В. Седова. Материаль 54 заседания (15-17 апреля 2008 года) (Псков: [s.n.], 2009), 363-381.

6 Radosław Liwoch, “Buławy z zachodniej Ukrainy”, Acta Militaria Mediaevalia, 2 (2006), 67-78.

7 Arkadiusz Michalak, "Wpływy wschodnie czy południowe? Z badań nad pochodzeniem buław średniowiecznych na ziemiach polskich", Вісник Національного університету “Львівська політехніка", 571 (2006), 48-74.

8 Māris Atgāzis, "Kaujas vāles Latvijā 10.-14. gadsimtā", Latvijas Vēstures Institūta Žurnāls, 2 (1999), 16-33

9 Fred Sandstedt, “'Hafdi kylfu stóra hendi” - Ett bidrag till kunskapen om den tidigmedeltida stridsklubban", Meddelande 52. Armémuseum årsbok 1992 (Stockholm, 1992), 73-103.

10 Adam Daubney, "Medieval Copper-alloy Mace-heads from England, Scotland and Wales", Decade of Discovery: Proceedings of the Portable Antiquities Scheme Conference 2007, ed. by

11 Ain Mäesalu, Jüri Peets, “Sõjanuiad, võimusümbolid ja margapuud?”, Ilusad asjad. Tähelepanuväarseid leide Eesti arheoloogiakogudest, ed. by Ulle Tamla. Muinasaja teadus, 10 (Tallinn, 2010), 211-236; Ain Mäesalu, "Estlands schönste Streitkeule des 12.-13. Jahrhunderts", Baltic Journal of Art History, 2 (2010), 201-220.

12 Hans Hildebrand, "Bronsklubborna", Kungl. Vitterhets-, historie- och antikvitetsakademiens Månadsblad (Stockholm, 1875), 22; Sigurd Grieg, "Hugg- og støtvåpen fra middelalderen", Rinne, "Sotanuijista museomme kokoelmissa", Suomen Museo, XVI (1909), 55, fig. 16.

13 Matts Dreijer, "Sundsklubban - nod till korsatav", Åländsk odling: årsbok 1978, 39 (§̊lands folkminnesförbund, 1978), 43-48.
The objective of this article is to analyse the macehead found in Papsaare in detail, to try and date it and discuss the initial function of the object.

\section{THE APPEARANCE OF THE PAPSAARE MACEHEAD}

The macehead under analysis cast from bronze. There are two images of human faces on the opposite sides of its centre section (Fig. 1A-B), and between them are hemispheres which are divided into six "leaves" (Fig. 1C-D).

The height of the macehead is $5,2 \mathrm{~cm}$ and the maximum diameter across the human faces is $4,9 \mathrm{~cm}$. The diameter of the shaft cavity is $1,35 \mathrm{~cm}$ from above (Fig. 1E) and about 1,65 cm from below (Fig. 1F). A part of the wooden shaft has been preserved in the shaft cavity. The initial weight of the macehead with the vestiges of wood in the inner cavity was 217 grams.

The faces clearly depict men. Since maceheads were used as weapons, then the parts of the men's faces that protrude, like the forehead, nose and chin, which were used for striking blows, have been damaged. The raised hemispheres between the faces on the sides of the macehead are separated into "leaves" by curved grooves. These six-leaved hemispheres are unique, because until now, none of the maceheads that have been found elsewhere include such an element.

Since this is an artistic object from the Middle Ages, one might assume that its ornamentation was inspired by Christian symbols. But unfortunately, it is impossible to suggest any clearly recognisable interpretations. The meaning of the six-leaved hemispheres between the faces is also difficult to explain. At first glance, they are somewhat reminiscent of flowers, but perhaps they are cloverleaves?

Looking down on the Papsaare macehead, the rusted remnants of nails are visible in the middle of the wooden shaft (Fig. 1E). Probably, a nail was driven into the wooden shaft from above to help secure the macehead to the shaft. Since, traces of rust also appear on the upper edge of the macehead, the diameter of the nail head made have been quite large, or maybe even artistically forged? Unfortunately, it has totally rusted away.

The initial metallographic analysis of the surface of the Papsaare macehead indicated the presence of noteworthy quantities of tin and 
Fig. 2. Macehead found in Örekilsälven, Sweden. Axel Emanuel Holmberg, Nordbon under hednatiden: populär framställning af våra förfäders äldsta kultur (Stockholm: J.T. Bergelin, 1852).

lead. ${ }^{14}$ It is not impossible that the macehead was initially coated with a layer of tin and lead, and therefore, may even have shone like silver.

The discovery site in the village of Papsaare is in the vicinity of an old road. This was an important road that started in the south, at least as far south as Riga, and continued north along the seaside. It was used to travel to North-Estonia, West-Estonia and Saaremaa Island.

\section{MACEHEADS WITH IMAGES OF HUMAN FACES FROM NEIGHBOURING COUNTRIES}

One macehead from Sweden and another from Norway, both with the image of a man's face, are somewhat similar to the Papsaare find. Previously, the macehead found in Örekilsälven, in Bohuslän County, Sweden, was thought to originate from either the Bronze Age or the modern era (Fig. 2). ${ }^{15}$ The macehead discovered in Norway, in the Sandviken district of Bergen, has the face of a sneering man on one side (Fig. 3A-B). ${ }^{16}$

14 Research conducted by Ragnar Saage at the Archaeological Lab at the University of Tartu

15 Axel Emanuel Holmberg, Nordbon under hednatiden: populär framställning af vår förfäders äldsta kultur (Stockholm: J.T. Bergelin, 1852), 36; Hildebrand, "Bronsklubborna", 22; Rinne, "Sotanuijista museomme kokoelmissa", fig. 16.

Fig. 1. Papsaare macehead: A-D - side views, E - top view, F - bottom view. Photo: Ain Mäesalu. 

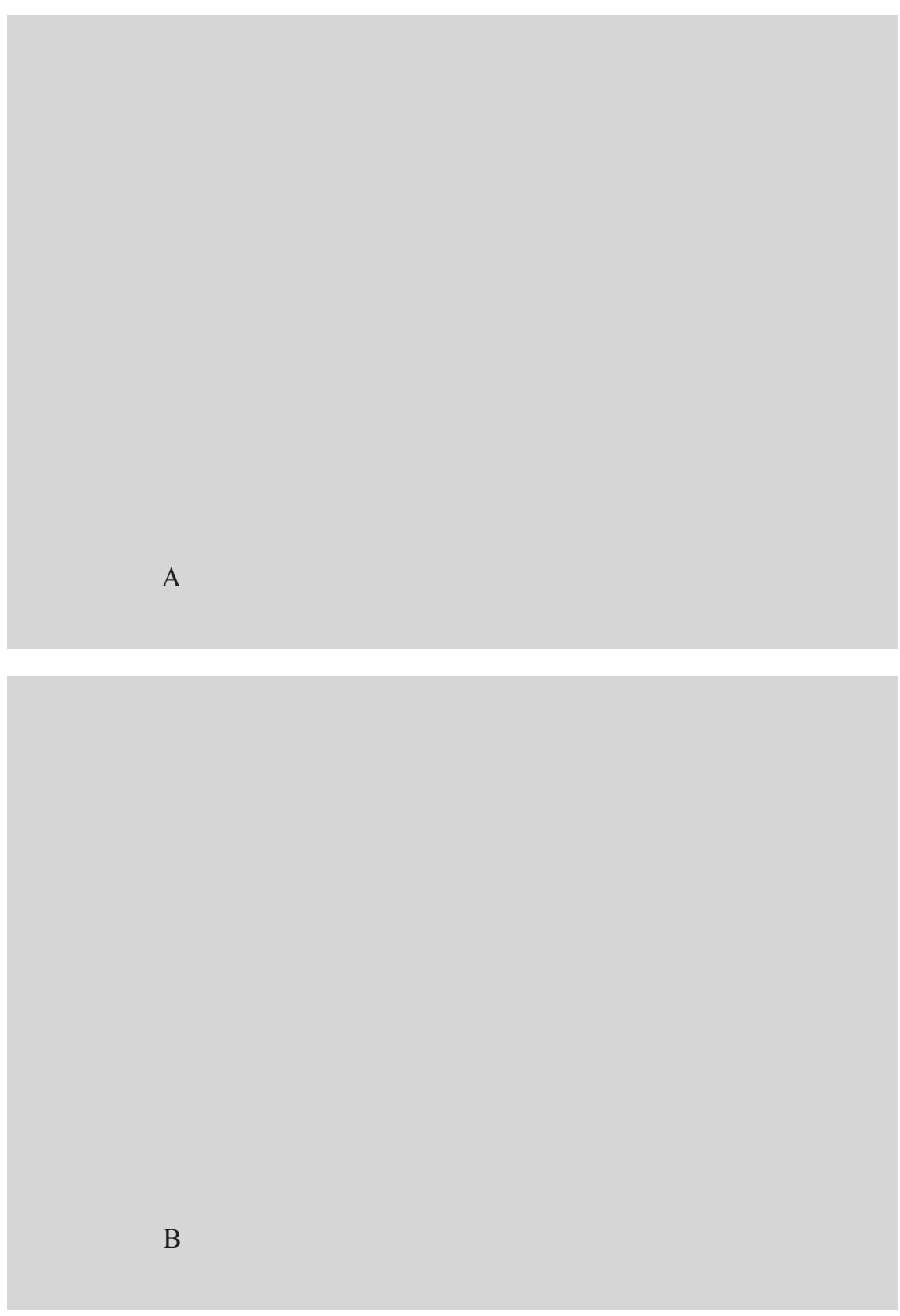

Fig. 3. A - The face of a sneering man is depicted on a macehead found in Sandviken, Norway. (Acc.no. Ma 323.) Photo: Svein Skare, Courtesy of the University Museum of Bergen.

作 Svein Skare, Courtesy of the University Museum of Bergen.

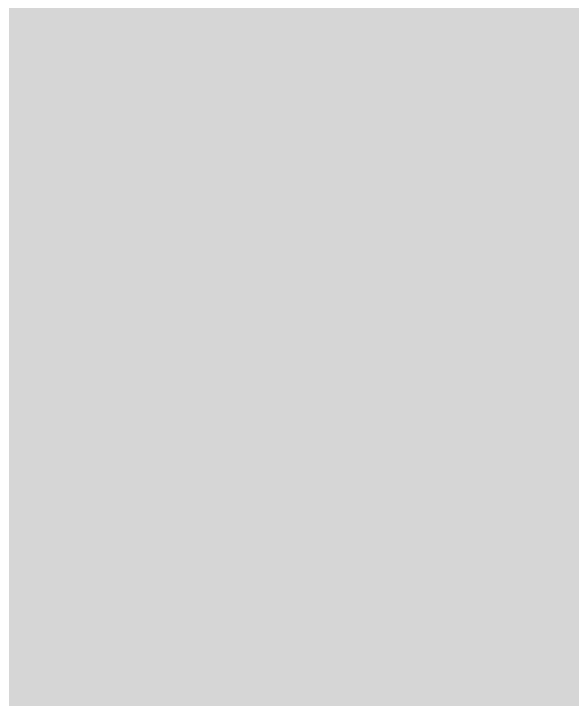

Fig. 4. Stamp with the image of the macehead found in Finby, Åland Islands.

and Norway, ${ }^{19}$ it can be assumed that are under examination may have originated from the same time period, i.e. from the $2^{\text {nd }}$ half of the $12^{\text {th }}$ century to the $13^{\text {th }}$ century.

In addition to the maceheads with two images of men's faces, an example has been found in Finby, on the Aland Islands, which has two full-length human figures (Fig. 4). This figure of a cleric or saint has his right hand raised, and his left hand is holding a book (scriptures) with the image of an X on the cover.

Matts Dreijer, who worked as an archaeologist for a long time on the Åland Islands, has written an article about the Finby macehead. ${ }^{20}$ Since the X-shaped cross is associated primarily with St Andrew, who was honoured most in medieval Byzantium, but also in Russia, he considered the macehead to be in the so-called 'Byzantine style'.

17 Кирпичников, “Древнерусское оружие, 2. Копья, сулицы, боевые топоры, булавы, кистени IX-XIII вв", 51-54, plate XXVI: 1-4; XXVII: 1-7; XXIX: 1-3.

18 Ain Mäesalu, "A rare macehead from the village of Tammeküla, Hargla paris", Archaeological Fieldwork in Estonia / Arheoloogilised välitööd Eestis 2009 (Tallinn: Muinsuskaitseamet, 2010)

19 Sandstedt, "Hafdi kylfu stóra hendi", 80-84, type A; Grieg, "Hugg- og støtvåpen fra middelalderen", 125-126, fig. 101.

20 Dreijer, "Sundsklubban - nod till korsatav", 43-48. 
Actually, Dreijer does not even call it a macehead, but a sceptre that belonged to Archbishop Unni of Bremen. It is known that Unni died on 17 September 936 in Birka. Dreijer, who was a great Åland Islands patriot, suggested that Birka was not even located in Sweden, but actually on the Åland Islands, and he thought that this macehead was initially located on Unni's grave. ${ }^{21}$ However, the majority of historians and archaeologists are convinced that Birka was located in Sweden on an island in Lake Mälar, and therefore, it is not believable that the macehead found in Finby could be associated with Archbishop Unni.

The maceheads produced and used in Byzantium only have various knops, spikes or ribs on all sides, but no figures. ${ }^{22}$ The examples that are most similar can be found among the maceheads from Bulgaria. ${ }^{23}$ The maceheads discovered in Russia also have sharp corners, protruding spikes, knops and ribs; and some also have geometric ornamental elements, but not images of human faces or human figures.

In order to ascertain the origin of the Finby macehead, I would like to focus on the details found on this find. It only has three rows of unusual slightly curved knops in the upper portion, which are not encountered, for instance, on the maceheads in Byzantium or Russia. Some maceheads which are similar in shape, and also have their lower portions decorated, but with spiral ornamentation, come from Poland, the Czech Republic and Germany. ${ }^{24}$ A very fancy example comes from Ahtenry, in Gallway, Ireland, which has beautifully designed columns under the knops and plant ornamentation on the lower portion. ${ }^{25}$

Based on its general appearance and the decorative elements, the Finby macehead can, first of all, be dated back to the second half of the $12^{\text {th }}$ century or the $13^{\text {th }}$ century. This object was probably associated with Christianization or even the Crusades.

21 Dreijer, "Sundsklubban - nod till korsatav", 47

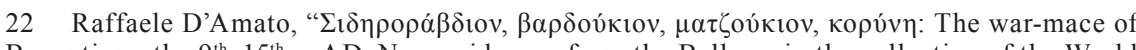
Dew evidences from the Balkans in the collection of Museum of Man, Florida”, Acta Militaria Mediaevalia, VII (Kraków, Rzeszów, Sanok, 2011), 7-48.

23 Popov, The Maces from the Present Bulgarian Lands $\left(10^{\text {th }}-17^{\text {th }} \mathrm{c}\right.$. AD).

24 Arkadiusz Michalak, "O dwóch średniowiecznych buławach z Pomorza Zachodniego", Wojskowość ludów Morza Bałtyckiego. Mare Integrans. Studia nad dziejami wybrzeży Morza Battyckiego. Materiaty z II Międzynarodowej Sesji Naukowej Dziejów Ludów Morza Battyckiego, Wolin 4-6 sierpnia $2006 r$., ed. by Michał Bogacki, Maciej Franz, Zbigniew Pilarczyk (Toruń, 2007), 132-137, fig. 4: 1-4; Rinne, "Sotanuijista museomme kokoelmissa", fig. 12.

25 Daubney, "Medieval Copper-alloy Mace-heads from England, Scotland and Wales", 204, fig. 6.

\section{A WEAPON OR A SYMBOL OF POWER?}

Archaeologists and weapons historians believe that maces with bronze or iron heads that were popular between the $11^{\text {th }}$ and $14^{\text {th }}$ centuries were often used as weapons. For example, the $13^{\text {th }}$ century chronicles that deal with the Crusades in the Baltic countries mention the local people using maces as weapons. ${ }^{26}$

Several weapons researchers have suggested that some of the maces may have been symbols of power that indicated a higher status. Several medieval works of art from various countries also allude to this possibility. ${ }^{27}$ This opinion might also be supported by that fact, compared to other weapons, such as spearheads, battleaxes and swords, the metal maceheads are relatively rare between the $11^{\text {th }}$ and $14^{\text {th }}$ centuries in many European countries.

The discovery contexts of the three maceheads resembling cubes with faceted corners that have been found in Estonia allude to the possibility that they were not only weapons but may also be been symbols of power for certain people of a higher status. ${ }^{28}$

We also see one such mace in a sculptural group in the Karja Church on Saaremaa Island (Fig. 5), which it has been suggested was produced between 1262 and $1285 .{ }^{29}$ Art historians believe that a legend associated with St Nicholas is depicted on it, according to which St Nicholas returned a youth, who had been kidnapped to be a wine pourer, back to a pagan noble. ${ }^{30}$ Since, in the $13^{\text {th }}$ century, Estonian parents on Saaremaa had sons who were being held as hostage by the Crusaders, the "maceman" that is depicted may also be a local noble whose child was brought back from abroad. ${ }^{31}$

Interesting information can be found in two documents compiled in Tallinn between 1360 and 1368, which list the commanders of the 26 Heinrich von Lettland, Livländische Chronik, transl. by Albert Bauer (Würzburg: Holzner Verlag von Ferdinand Schöningh, 1876), 3886, 10706; for more, Mäesalu, "Estlands schönste Streitkeule des 12.-13. Jahrhunderts”, 208-210.

27 For more, Mäesalu, "Estlands schönste Streitkeule des 12.-13. Jahrhunderts", 211.

28 Mäesalu, Peets, "Sõjanuiad, võimusümbolid ja margapuud?”, 218-221.

29 Helen Bome, Kersti Markus, "Karja kirik - kõige väiksem "katedraal”", Kunstiteaduslikke Uurimusi, 4 (14) (2005), 10

30 Bome, Markus, "Karja kirik - kõige väiksem "katedraal”", 24.

31 Ibidem; Mäesalu, "Estlands schönste Streitkeule des 12.-13. Jahrhunderts", 213-214. 


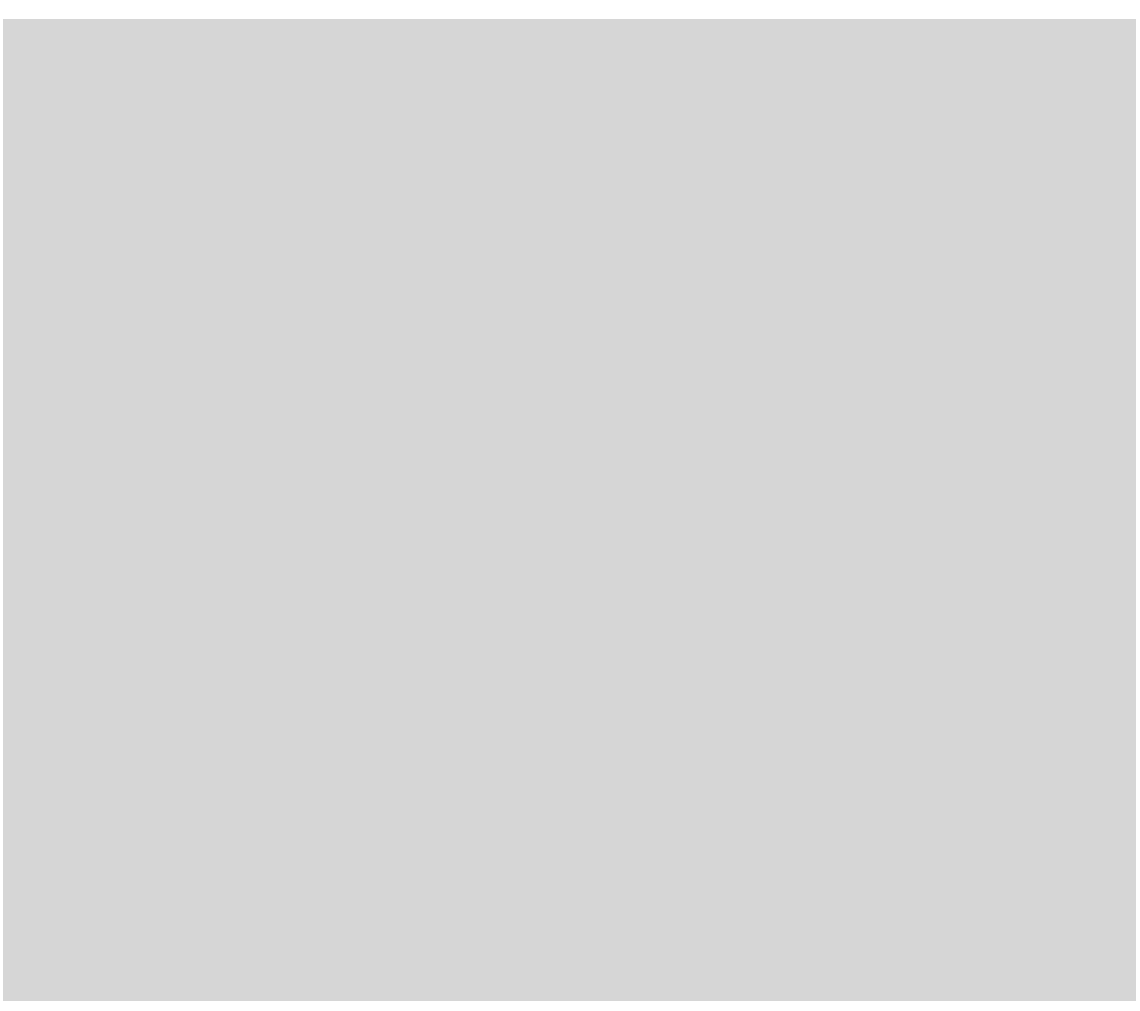

Fig. 5. Sculptural group in the Karja Church, which probably depicts an Estonian noble with his son who was returned after being held hostage. Photo: Rein Maran, Archive
of the National Heritage Board.

town wall towers, and the weapons supplied by the town to defend them. ${ }^{32}$ It is not impossible that the maces on those lists were the symbols of power for the tower commanders. ${ }^{33}$

\section{IN CONCLUSION}

The Papsaare macehead is a unique find, and not only in Estonia It is also among the rarest maceheads in all of Northern Europe. Considering the dating of the maceheads that have been compared above, one can assume that the Papsaare macehead may have been

32 Libri de diversis articulis 1333-1374, ed. by Paul Johansen. Publikationen aus dem Stadtarchiv Tallinn, 8 (Tallinn, 1935), XXX, No. 531-532.

33 For more, Mäesalu, "Estlands schönste Streitkeule des 12.-13. Jahrhunderts", 214-215. produced either at the end of the $12^{\text {th }}$ century or in the $13^{\text {th }}$ century. Although very few maceheads with men's faces and human figures have been found, three of the four examples come from the Baltic Sea countries, and the Papsaare macehead was apparently also produced in this area.

This macehead may have belonged to a highborn noble or a military commander, and been used primarily as a symbol of power. Since the mace's cavity is only 1,35 to $1,65 \mathrm{~cm}$ in diameter, the shaft that would fit could easily break if used to deliver a blow. Of course, it could be used as a weapon if necessary. And it was probably used as a weapon to deliver the last blow. It is possible that the opponent had a strong helmet or the macehead struck the edge of shield, which resulted in the wooden shaft, and the lower part of the macehead pipe, shattering. The small macehead fell into the snow or grass, and was very difficult to find.

Ain Mäesalu: The Artistic Papsaare Macehead - Weapon or SYMBOL OF POWER?

Keywords: Medieval Weapons; medieval macehead; medieval POWER SYMBOL; MEDIEVAL ART

\section{SUMMARY}

The article provides a survey of an archaeological find from 2016 a macehead of moulded bronze found in the village of Papsaare in Pärnu County. Human faces are depicted on two opposite side of the middle section with hemispheres between them that are separated by grooves into six "leaves".

Maceheads with images of humans are extremely rare in Europe. Until now, only one macehead with a man's face was known to exist from Sweden, and another from Norway. A macehead with the full figures of two clerics was found in Finby, on the Aland Islands. The Papsaare macehead was apparently produced in the second half of the $12^{\text {th }}$ century or the $13^{\text {th }}$ century somewhere in northern Europe. It was probably the power symbol of a noble or military leader, which could also be used as a weapon if necessary. 


\section{CV}

Ain Mäesalu (b. 1955) is an archaeologist, who has worked for 33 years as a lecturer on archaeology at the University of Tartu. He had dealt with the archaeological research of Estonia's medieval castles and the city of Tartu, and written numerous articles on medieval weaponry. 